\title{
Crude glycerin combined with food additives in feeding beef cattle
}

\author{
Marco Túlio Costa Almeida ${ }^{1^{*}}$ (iD), Jane Maria Bertocco Ezequiel ${ }^{1}$, Josimari Regina \\ Paschoaloto', Vanessa Barbosa de Carvalho', Henrique Leal Perez', Vanessa Ruiz Fávaro1, \\ André Pastori D'Aurea', Antonio Carlos Homem Junior ${ }^{1}$
}

\footnotetext{
${ }^{1}$ Universidade Estadual Paulista, Faculdade de Ciências Agrárias e Veterinárias, Jaboticabal, SP, Brasil.
}

\begin{abstract}
The objective of this study was to evaluate the effects of adding crude glycerin with food additives (sodium monensin or essential oils) to the diets of beef cattle on feed intake, ruminal parameters, in vitro digestibility, and production of greenhouse gases. Five ruminally cannulated Nellore steers were randomly assigned in a $5 \times 5$ Latin square design. The treatments were: control, without crude glycerin and additives; with essential oils and without crude glycerin; with sodium monensin and without crude glycerin; with essential oils and crude glycerin; and with sodium monensin and crude glycerin. The addition of crude glycerin caused a reduction in dry matter (DM) intake, increase in vitro dry matter digestibility, and decrease in vitro crude protein digestibility, regardless of the food additive. All treatments were effective in maintaining the rumen environment with $\mathrm{pH}$ values above 6.2 and ammonia nitrogen concentrations above $10 \mathrm{mg} \mathrm{dL}^{-1}$. No difference was observed in the production and quality of protozoal and bacterial fractions. The addition of crude glycerin at $200 \mathrm{~g} \mathrm{~kg}^{-1} \mathrm{DM}$ in the total diet can partially replace corn grain and soybean hulls and be combined with either sodium monensin or essential oil without impairing the rumen fermentation, being effective in reducing gas methane production and, when combined with sodium monensin, enables more efficient utilization of the diet by the animal. Therefore, feedlot experiments at large scales of production should be evaluated to prove these positive results.
\end{abstract}

Key Words: byproduct, essential oil, ruminal parameters, sodium monensin

\section{Introduction}

Glycerin is the major byproduct of the conversion of vegetable oils and fats into biodiesel. Approximately $10 \%$ of the total production becomes crude glycerin (Tan et al., 2013). The use of crude glycerin as an alternative energy source in ruminant diets has shown promising results (Ezequiel et al., 2015; Favaro et al., 2016; Almeida et al., 2017), mainly as a replacement for corn grain.

In addition to the opportunity of byproduct utilization, the use of growth promoters (ionophores) in ruminant diets has been used to maximize energy efficiency and utilization of dietary nutrients with even more favorable economic results. Sodium monensin is an ionophore antibiotic widely used and well documented in ruminant feeding mainly to minimize metabolic disorders and improve energy efficiency of diets (Azzaz et al., 2015).

Received: April 26, 2017

Accepted: May 1, 2018

*Corresponding author: marcotulio695@yahoo.com.br

Copyright (c) 2018 Sociedade Brasileira de Zootecnia. This is an Open Access article distributed under the terms of the Creative Commons Attribution License (http://creativecommons.org/licenses/by/4.0/), which permits unrestricted use, distribution, and reproduction in any medium, provided the original work is properly cited.
However, the ordinary use of antibiotics in animal feed has worried public health (Benchaar et al., 2006), because the inappropriate use could compromise the therapeutic action of antibiotics in humans (Dewulf et al., 2007; Ray et al., 2007). To meet the constraints imposed by some consumer markets (e.g., the banning of sodium monensin as a growth promoter by the European Union, Regulation EC no. 1831/2003), animal nutritionists are researching new alternatives to ionophores, such as essential oils.

Essential oils are mixtures of compounds obtained from plants. Functional properties against microorganisms and antioxidant activities have been reported for many essential oils (Busquet et al., 2005a,b; Duarte et al., 2007). The essential oil composed of a blend of shell liquid of cashew nut and castor oil has shown positive results as a replacement for sodium monensin (Jesus et al., 2016), and when combined with crude glycerin, has shown good results on performance in feedlot beef cattle (Cruz et al., 2014; Valero et al., 2014; Prado et al., 2015). Nevertheless, in vitro and in situ studies evaluating the kinetics and ruminal fermentation of this association have not yet been reported. We hypothesized that this interaction could provide similar or better ruminal conditions when compared with sodium monensin combined with crude glycerin. 
Thus, this study was performed to evaluate the effects of adding crude glycerin (200 $\mathrm{g} \mathrm{kg}^{-1} \mathrm{DM}$ ) with sodium monensin or essential oils to diets of Nellore cattle on intake and in vitro DM and nutrient digestibility, ruminal parameters, and in vitro gas production.

\section{Material and Methods}

The study was conducted in Jaboticabal, SP, Brazil $\left(21^{\circ} 14^{\prime} 05^{\prime \prime} \mathrm{S}\right.$ latitude, $48^{\circ} 17^{\prime} 09^{\prime \prime} \mathrm{W}$ longitude, and $615.01 \mathrm{~m}$ elevation). The cannulation procedures and use of ruminally cannulated animals were conducted according to the institutional committee on animal use (case no. 028066/12).

Five ruminally cannulated Nellore steers of $\sim 26$ months of age and $550 \mathrm{~kg}$ body weight (BW) were housed in individual semi-roofed, concrete-surfaced pens $\left(16 \mathrm{~m}^{2}\right)$, with concrete floor, provided with individual feed bunkers and drinkers. The experiment was a $5 \times 5$ Latin square design, in a $2 \times 2+1$ factorial arrangement (sodium monensin or essential oils $\times$ absence or presence of crude glycerin + control). The experimental period lasted 21 days, 14 days for adaptation to diets and seven days for data collection.

Five diets similar in crude protein and metabolizable energy concentrations were formulated using the Cornell Net Carbohydrate and Protein System 5.0.40 (CNCPS, 2000), using the software LRNS 1.0.29, respecting the nutritional requirements of animals (NRC, 1996). The roughage:concentrate ratio of diets was 30:70, comprising the treatments: without crude glycerin and additives (control); with essential oils and without crude glycerin; with sodium monensin and without crude glycerin; with essential oils and crude glycerin; and with sodium monensin and crude glycerin (Table 1).

The commercial product with essential oils used in this trial was Essential ${ }^{\circledR}$ (Oligo Basics, Cascavel, PR, Brazil), which consists of active ingredients derived from oils of castor beans and cashew nuts, with about $9 \%$ castor oil (ricinoleic acid) and 36\% cashew oil (anacardic acid, cardol and cardanol), and the sodium monensin used was Rumenpac $^{\circledR}$ (MCassab, São Paulo, SP, Brazil).

The inclusion of crude glycerin was $200 \mathrm{~g} \mathrm{~kg}^{-1} \mathrm{DM}$ in the total diet, replacing $50 \%$ of corn grain and $13.27 \%$ of soybean hull in the treatments with essential oils and crude glycerin and with sodium monensin and crude glycerin. The crude glycerin used was derived from crude soybean oil and contained approximately $830.0 \mathrm{~g} \mathrm{~kg}^{-1}$ glycerol, $109.9 \mathrm{~g} \mathrm{~kg}^{-1}$ water, $60 \mathrm{~g} \mathrm{~kg}^{-1}$ salts, and less than $0.1 \mathrm{~g} \mathrm{~kg}^{-1}$ methanol.

Animals were fed twice a day (07:00 and 19:00 h) and received water ad libitum. The additives were homogenized with mineral supplement and mixed with the other ingredients for the manufacture of concentrate, with

Table 1 - Ingredient and chemical composition of the experimental diets

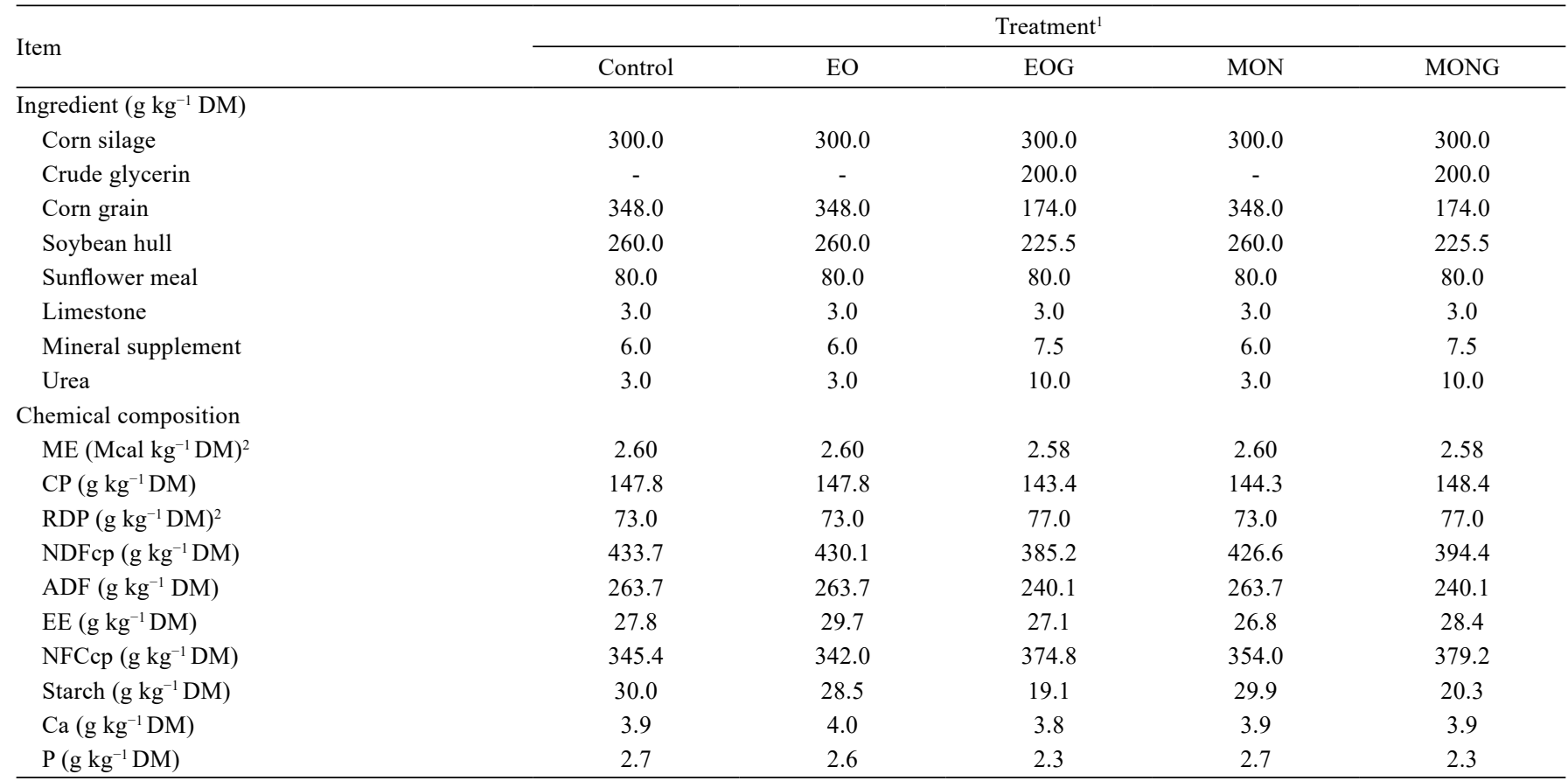

DM - dry matter; ME - metabolizable energy; CP - crude protein; RDP - rumen-degradable protein; NDFcp - neutral detergent fiber corrected for ash and protein; ADF - acid detergent fiber; EE - ether extract; NFCcp - non-fiber carbohydrates corrected for ash and protein.

${ }^{1}$ Control: with no addition of crude glycerin and additives; EO: essential oils with no addition of crude glycerin; EOG: essential oils added with crude glycerin; MON: sodium monensin with no addition of crude glycerin; MONG: sodium monensin added with crude glycerin.

${ }^{2}$ Estimated according to equation of CNCPS (2000). 
the following levels: $0.5 \mathrm{~g} \mathrm{~kg}^{-1} \mathrm{DM}$ Essential ${ }^{\circledR}$ in the treatments with essential oils and without crude glycerin and with essential oils and crude glycerin and $0.03 \mathrm{~g} \mathrm{~kg}^{-1}$ DM Rumenpac ${ }^{\circledR}$ in the treatments with sodium monensin and without crude glycerin and with sodium monensin and crude glycerin.

After adaptation, voluntary intake was determined by daily weighing of feed and orts. Samples of orts and feed were taken for six days, from the 16th to the $21 \mathrm{st}$ day, and ingredients were sampled at the beginning of each experimental period. Samples were pooled for each experimental period, dried in a forced-air circulation oven at $55{ }^{\circ} \mathrm{C}$ for $72 \mathrm{~h}$, and ground in a Wiley mill with $1-\mathrm{mm}$ sieve for future analysis.

Samples were analyzed for DM, ash, crude protein (CP), and ether extract (EE) according to AOAC (2000); total starch was determined according the method described by Hendrix (1993); neutral detergent fiber corrected for ash and protein (NDFcp) and acid detergent fiber (ADF), by using the solutions proposed by Van Soest and Wine (1967), and digestion performed in an autoclave $\left(0.5 \mathrm{Kgf} \mathrm{cm}^{2-1}\right.$, $110^{\circ} \mathrm{C}$ ) for $50 \mathrm{~min}$. After this time, the samples were filtered on a sintered glass funnel, washed five times with 100 $\mathrm{mL}$ of hot distilled water, rinsed with acetone, and dried overnight at $55{ }^{\circ} \mathrm{C}$ (Pell and Schofield, 1993). Non-fiber carbohydrates corrected for ash and protein (NFCcp) were calculated according to Sniffen et al. (1992).

The $\mathrm{pH}$ and ruminal ammonia $\left(\mathrm{NH}_{3}-\mathrm{N}\right)$ concentration were determined taking samples from the rumen content $(100 \mathrm{~mL})$ via ruminal cannula upon feeding $(0 \mathrm{~h}), 1,2,4,6$, 8 , and $12 \mathrm{~h}$ after morning feeding on the 16th day of each experimental period. The $\mathrm{pH}$ was measured immediately after filtration of the liquid using a digital $\mathrm{pH}$ meter (Digimed DM-20), and the concentration of $\mathrm{NH}_{3}-\mathrm{N}$ was determined in micro-Kjeldahl equipment using $5 \mathrm{~mL} 2 \mathrm{~N}$ $\mathrm{KOH}$ and a distillation flux of $2 \mathrm{~mL} \mathrm{~min}{ }^{-1}$. The distilled sample was dropped into $10 \mathrm{~mL}$ boric acid solution (2\%) and then titrated with $0.005 \mathrm{~N} \mathrm{HCl}$.

The production of $\mathrm{CH}_{4}$ and $\mathrm{CO}_{2}$ was estimated by the in vitro technique on the 17 th day of each period, according to adapted methodology of Pereira et al. (2006). Approximately $150 \mathrm{~mL}$ of filtered rumen fluid was poured into a $250-\mathrm{mL}$ "Erlenmeyer" flask containing $2.1 \mathrm{~g}$ of predried sample of the total diet $(1 \mathrm{~mm})$. Flasks containing samples and rumen fluid were kept for $12 \mathrm{~h}$ in a shaker incubator, with constant stirring at $39{ }^{\circ} \mathrm{C}$, and the gases produced were stored in PET bottles. After incubation, an aliquot from each sample was collected directly from the flask with the aid of a syringe $(1 \mathrm{~mL})$ and immediately injected into a gas chromatograph (Trace GC Ultra, Thermo
Scientific), which generated the percentages of $\mathrm{CO}_{2}$ and $\mathrm{CH}_{4}$. The total amount of gas produced was measured by determining the volume occupied by the gas produced in the bottles after $12 \mathrm{~h}$ of fermentation. The disappearance rate of DM (DMD) and of neutral detergent fiber (NDFD) of the diets incubated was calculated after centrifugation for $3 \mathrm{~min}$ at $3000 \mathrm{rpm}$, separation and drying the residue in an oven, and subtracting the blank value (Chaudhry and Khan, 2012).

The concentration of protozoal and bacterial fractions was determined by collecting approximately $3 \mathrm{~kg}$ of rumen content, upon feeding $(0 \mathrm{~h}), 2,5$, and $8 \mathrm{~h}$ after morning feeding on days $18(0$ and $5 \mathrm{~h}$ ) and 19 ( 2 and $8 \mathrm{~h}$ ) of each experimental period. Samples were frozen $\left(-20^{\circ} \mathrm{C}\right)$ for later evaluation of the quality and quantity of microbial fractions in the different phases of the particle-associated bacteria (PAB), liquidassociated bacteria (LAB), and liquid-associated protozoa (LAP), according to the method described by Cecava et al. (1990), adapted by Martin et al. (1994).

The in vitro digestibility of DM and nutrients (NDF, $\mathrm{ADF}, \mathrm{CP}, \mathrm{EE}$, and NFC) were obtained by the $\mathrm{ANKOM}^{\circledR}$ technique on the 20th day of each experimental period. Ankom F57 filter bags ( $=25 ; 24$ with samples and 1 blank) were filled with substrates (ground at $1 \mathrm{~mm} ; 0.5 \mathrm{~g}$ ), heat-sealed, and placed into fermentation jars. A solution composed of $400 \mathrm{~mL}$ of rumen fluid, $1330 \mathrm{~mL}$ of buffer $\mathrm{A}$ (10.0 g L $\mathrm{KH}_{2} \mathrm{PO}_{4}, 0.5 \mathrm{~g} \mathrm{~L}^{-1} \mathrm{MgSO}_{4} \cdot 7 \mathrm{H}_{2} \mathrm{O}, 0.5 \mathrm{~g} \mathrm{~L}^{-1} \mathrm{NaCl}$, $0.1 \mathrm{~g} \mathrm{~L}^{-1} \mathrm{CaCl}_{2} \cdot 2 \mathrm{H}_{2} \mathrm{O}$, and $0.5 \mathrm{~g} \mathrm{~L}^{-1}$ urea), and $266 \mathrm{~mL}$ of buffer $\mathrm{B}\left(15.0 \mathrm{~g} \mathrm{~L}^{-1} \mathrm{Na}_{2} \mathrm{CO}_{3}\right.$ and $\left.1.0 \mathrm{~g} \mathrm{~L}^{-1} \mathrm{Na}_{2} \mathrm{~S} \cdot 9 \mathrm{H}_{2} \mathrm{O}\right)$ was prepared and placed into fermentation jars. The containers were purged with $\mathrm{CO}_{2}$ and placed into the pre-heated $\left(39^{\circ} \mathrm{C}\right.$ ) DaisyII fermenter. After 48 -h incubation, $40 \mathrm{~mL}$ of $6 \mathrm{~N} \mathrm{HCl}$ and $8 \mathrm{~g}$ of pepsin $(1: 10,000)$ were added to each digestion jar, and incubated for another $24-\mathrm{h}$ period. The filter bags containing residues of substrates were rinsed and manually washed and dried. Substrates and residues were evaluated for DM and nutrient contents, to calculate in vitro digestibilities.

All data were analyzed as a $5 \times 5$ Latin square design using the MIXED procedure of SAS (Statistical Analysis System, version 9.2.), following the mathematical model:

$$
\mathrm{Y}=\mu+\alpha_{\mathrm{i}}+\beta_{\mathrm{j}}+\gamma_{\mathrm{k}}+\varepsilon_{\mathrm{ijk} \mathrm{l}}
$$

in which $\mu=$ overall mean $\alpha_{i}=$ random effect of animal ( $\mathrm{i}=1$ to 5 ), $\beta_{\mathrm{j}}=$ random effect of period ( $\mathrm{j}=1$ to 5 ), $\gamma_{\mathrm{k}}=$ fixed effect of $\operatorname{diet}\left(\mathrm{k}=1\right.$ to 5 ), and $\varepsilon_{\mathrm{ijkl}}=$ residual error.

Data of $\mathrm{pH}, \mathrm{NH}_{3}-\mathrm{N}$ and microbial fractions (PAB, $\mathrm{LAB}$, and LAP) were considered as repeated measures. First, however, several covariance structures were tested, and the best one was chosen for each variable, based on 
Akaike information criterion $\left(\mathrm{pH}=\mathrm{TOEPH} ; \mathrm{NH}_{3}-\mathrm{N}=\right.$ TOEPH; PAB [ $\left.\mathrm{mg} \mathrm{kg}^{-1} \mathrm{DM}\right]=$ SIMPLE; LAB $\left[\mathrm{mg} \mathrm{kg}^{-1} \mathrm{DM}\right]$ $=$ TOEPH; LAP $\left[\mathrm{mg} \mathrm{kg}^{-1} \mathrm{DM}\right]=$ TOEPH; PAB $\left[\mathrm{mg} \mathrm{kg}^{-1}\right.$ organic matter $-(\mathrm{OM})]=\mathrm{FA}$; LAB $\left[\mathrm{mg} \mathrm{kg}^{-1} \mathrm{OM}\right]=\mathrm{CSH}$; LAP $\left.\left[\mathrm{mg} \mathrm{kg}^{-1} \mathrm{OM}\right]=\mathrm{FA}\right)$. The statistical differences of the parameters over time were determined using the following mathematical model:

$$
\mathrm{Y}=\left(\mu+\alpha_{\mathrm{i}}+\beta_{\mathrm{j}}+\gamma_{\mathrm{k}}+\varepsilon_{\mathrm{ijk}}+\lambda_{1}(\gamma \times \lambda)_{\mathrm{kl}}+\varepsilon_{\mathrm{ijk} \mathrm{l}}\right),
$$

in which $\mu=$ overall mean, $\alpha_{i}=$ random effect of animal ( $i=$ 1 to 5$), \beta_{\mathrm{j}}=$ random effect of period ( $\mathrm{j}=1$ to 5$), \gamma_{\mathrm{k}}=$ fixed effect of diet ( $\mathrm{k}=1$ to 5$), \varepsilon_{\mathrm{ijk}}=$ plot residual error, $\lambda_{1}=$ fixed effect of harvest time, $(\gamma \times \lambda)_{\mathrm{kl}}=$ interaction between diet and harvest time, and $\varepsilon_{\mathrm{ijkl}}=$ subplot residual error.

The results were tested by analysis of variance and Tukey's test and checked for interactions between time and treatment at $5 \%$ probability, breaking down interactions whenever necessary. Contrasts were used to define the effects of treatments in case of absence of interaction. The contrasts include the effect of additives (sodium monensin vs. essential oils), effects of association of additives with crude glycerin (additive + crude glycerin $v s$. additive), and effects of inclusion of additives (control $v s$. additives).

All statistical procedures were run using SAS at 5\% probability $(\alpha=0.05)$.

\section{Results}

The use of food additives had no influence on DMI of animals ( $>0.05$; Contrast 1) (Table 2). However, when combined with crude glycerin, a reduction was observed $(\mathrm{P}<0.05$; Contrasts 2 and 3). Treatments with sodium monensin showed lower DMI in comparison with treatments with essential oils ( $\mathrm{P}<0.05$; Contrast 4$)$.

Food additives promoted greater DM and EE digestibility and lower NFC digestibility when compared with the control treatment $(\mathrm{P}<0.05$; Contrast 1) (Table 2). The combination of crude glycerin with additives increased DM digestibility and reduced CP digestibility of the diets $(\mathrm{P}<0.05$; Contrasts 2 and 3$)$. Increases on digestibility of OM $(\mathrm{P}<0.05$; Contrast 2$)$ and NFC $(\mathrm{P}<0.05$; Contrast 3$)$ were observed when crude glycerin was combined with essential oil and sodium monensin, respectively. Treatments with essential oils resulted in higher NFC digestibility when compared with sodium monensin treatments $(\mathrm{P}<0.05$; Contrast 4).

There was no effect of the interaction between time and treatments for $\mathrm{pH}, \mathrm{NH}_{3}-\mathrm{N}$ concentrations, and none of the microorganism fractions $(\mathrm{P}>0.05)$, thus being analyzed the contrasts obtained from the mean values of harvest time. The combination of crude glycerin with additives did not influence the results of $\mathrm{pH}$ and $\mathrm{NH}_{3}-\mathrm{N}(\mathrm{P}>0.05)$ (Table 2). Treatments with sodium monensin led to reduction in $\mathrm{NH}_{3}-\mathrm{N}$ concentrations in relation to treatments with essential oil ( $\mathrm{P}<0.05$; Contrast 4 ).

The combination of crude glycerin with essential oils caused reductions in the amounts of DM and $\mathrm{OM}$ in $\mathrm{mg} \mathrm{kg}^{-1}$ ruminal content for liquid-associated bacteria $(\mathrm{P}<0.05$; Contrast 2) (Table 3). Food additives promoted reductions in $\mathrm{CH}_{4}$ and $\mathrm{CO}_{2}$ production $\left(\mathrm{mL} \mathrm{gd} \mathrm{gd}^{-1}\right)$ and increased the

Table 2 - Dry matter intake (DMI, $\mathrm{kg} \mathrm{day}^{-1}$ ), in vitro digestibility (IVD, $\mathrm{g} \mathrm{g}^{-1}$ ) of $\mathrm{DM}$ and nutrients, ruminal $\mathrm{pH}$, and $\mathrm{NH}_{3}-\mathrm{N}\left(\mathrm{mg} \mathrm{dL}^{-1}\right)$ concentrations of Nellore cattle fed diets containing food additives combined or not with crude glycerin

\begin{tabular}{|c|c|c|c|c|c|c|c|c|c|c|}
\hline \multirow{2}{*}{ Item } & \multicolumn{5}{|c|}{ Treatment $^{1}$} & \multirow{2}{*}{ SEM } & \multicolumn{4}{|c|}{ Contrast $^{2}, \mathrm{P}$-value } \\
\hline & Control & EO & EOG & MON & MONG & & 1 & 2 & 3 & 4 \\
\hline DMI & 7.81 & 8.75 & 7.63 & 8.15 & 6.65 & 0.20 & 0.9581 & 0.0013 & 0.0001 & 0.0013 \\
\hline \multicolumn{11}{|l|}{ IVD } \\
\hline DM & 0.5890 & 0.6067 & 0.6993 & 0.6108 & 0.6914 & 0.012 & 0.0099 & 0.0039 & 0.0093 & 0.9211 \\
\hline $\mathrm{OM}$ & 0.5366 & 0.5461 & 0.6201 & 0.5515 & 0.6192 & 0.014 & 0.0894 & 0.0423 & 0.0597 & 0.9236 \\
\hline NDF & 0.4685 & 0.5091 & 0.5119 & 0.4952 & 0.5408 & 0.017 & 0.1812 & 0.9475 & 0.2852 & 0.7990 \\
\hline $\mathrm{EE}$ & 0.8169 & 0.8501 & 0.8420 & 0.8389 & 0.8531 & 0.005 & 0.0119 & 0.5270 & 0.2741 & 0.9975 \\
\hline NFC & 0.9064 & 0.9095 & 0.8924 & 0.8391 & 0.8937 & 0.006 & 0.0042 & 0.0577 & $<0.0001$ & $<0.0001$ \\
\hline \multicolumn{11}{|c|}{ Ruminal parameter } \\
\hline $\mathrm{pH}^{3}$ & 6.12 & 6.09 & 6.12 & 6.17 & 6.12 & 0.03 & 0.9040 & 0.4350 & 0.2550 & 0.1870 \\
\hline $\mathrm{NH}_{3}-\mathrm{N}^{4}$ & 22.17 & 21.05 & 20.85 & 20.01 & 17.04 & 0.77 & 0.0520 & 0.9010 & 0.0600 & 0.0300 \\
\hline
\end{tabular}

DM - dry matter; OM - organic matter; NDF - neutral detergent fiber; ADF - acid detergent fiber; CP - crude protein; EE - ether extract; NFC - non-fiber carbohydrates; SEM standard error of the mean.

${ }^{1}$ Control: with no addition of crude glycerin and additives; EO: essential oils with no addition of crude glycerin; EOG: essential oils added with crude glycerin; MON: sodium monensin with no addition of crude glycerin; MONG: sodium monensin added with crude glycerin.

${ }^{2} 1=$ control versus additives (EO, EOG, MON, and MONG); $2=$ EO versus EOG; $3=$ MON versus MONG; $4=$ essential oils $($ EO and EOG) versus sodium monensin (MON and MONG).

${ }^{3}$ Regression equation $(\mathrm{pH} \times$ time $): \mathrm{pH}=0161 \mathrm{X}^{2}-0.1653 \mathrm{X}+6.3775\left(\mathrm{R}^{2}=0.9304\right)$.

${ }^{4} \mathrm{NH}_{3}-\mathrm{N}=$ ammonia concentration; regression equation $\left(\mathrm{NH}_{3}-\mathrm{N} \times\right.$ time $): \mathrm{NH}_{3}-\mathrm{N}=0.3371 \mathrm{X}^{3}-4.5391 \mathrm{X}^{2}+14.645 \mathrm{X}+15.508\left(\mathrm{R}^{2}=0.8893\right)$. 
Table 3 - Concentration of rumen microbial fractions, in vitro gas production, and disappearance of dry matter (DMD) and neutral detergent fiber (NDFD) of Nellore cattle fed diets containing food additives combined or not with crude glycerin

\begin{tabular}{|c|c|c|c|c|c|c|c|c|c|c|}
\hline \multirow{2}{*}{ Item } & \multicolumn{5}{|c|}{ Treatment $^{1}$} & \multirow{2}{*}{ SEM } & \multicolumn{4}{|c|}{ Contrast $^{2}, \mathrm{P}$-value } \\
\hline & Control & $\mathrm{EO}$ & EOG & MON & MONG & & 1 & 2 & 3 & 4 \\
\hline \multicolumn{11}{|c|}{ Microbial fraction $\left(\mathrm{mg} \mathrm{kg}^{-1} \mathrm{DM}\right)^{3}$} \\
\hline PAB & 4756.33 & 4649.44 & 4523.44 & 4931.39 & 4447.61 & 186.13 & 0.6786 & 0.9820 & 0.3637 & 0.6150 \\
\hline $\mathrm{LAB}$ & 587.97 & 641.34 & 494.83 & 625.08 & 540.77 & 26.14 & 0.9784 & 0.0094 & 0.5673 & 0.5324 \\
\hline LAP & 1101.48 & 1250.92 & 1387.13 & 1099.93 & 1375.46 & 93.61 & 0.5925 & 0.9254 & 0.7366 & 0.9263 \\
\hline \multicolumn{11}{|c|}{ Microbial fraction $\left(\mathrm{mg} \mathrm{kg}^{-1} \mathrm{OM}\right)^{4}$} \\
\hline LAP & 662.01 & 745.69 & 718.79 & 593.54 & 764.85 & 46.92 & 0.9151 & 0.6454 & 0.5123 & 0.7916 \\
\hline \multicolumn{11}{|c|}{$\operatorname{Gas}\left(\mathrm{mL} \mathrm{g}^{-1}\right)$} \\
\hline $\mathrm{CH}_{4}$ & 8.93 & 9.14 & 9.19 & 7.8 & 6.17 & 0.37 & 0.0785 & 0.9832 & 0.1239 & 0.0133 \\
\hline $\mathrm{CO}_{2}$ & 29.43 & 31.45 & 30.06 & 30.71 & 28.57 & 0.72 & 0.8462 & 0.8037 & 0.2475 & 0.1485 \\
\hline \multicolumn{11}{|c|}{$\operatorname{Gas}\left(\mathrm{mL} \mathrm{gd}^{-1}\right)$} \\
\hline NDFD & 0.2148 & 0.2552 & 0.2093 & 0.2292 & 0.2138 & 0.006 & 0.2149 & 0.0004 & 0.2107 & 0.2157 \\
\hline
\end{tabular}

DM - dry matter; PAB - particle-associated bacteria; LAB - liquid-associated bacteria; LAP - liquid-associated protozoa; SEM - standard error of the mean.

${ }^{1}$ Control: with no addition of crude glycerin and additives; EO: essential oils with no addition of crude glycerin; EOG: essential oils added with crude glycerin; MON: sodium monensin with no addition of crude glycerin; MONG: sodium monensin added with crude glycerin.

${ }^{2} 1$ = control versus additives (EO, EOG, MON, and MONG); $2=$ EO versus EOG; $3=$ MON versus MONG; $4=$ essential oils (EO and EOG) versus sodium monensin (MON and MONG).

${ }^{3}$ Regression equation of microbial fractions $\left(\mathrm{mg} \mathrm{kg}{ }^{-1} \mathrm{DM}\right) \times$ time: $\mathrm{PAB}=-22.066 \mathrm{X}^{3}+359.18 \mathrm{X}^{2}-1529.3 \mathrm{X}+5520.7\left(\mathrm{R}^{2}=0.9989\right) ; \mathrm{LAB}=4.729 \mathrm{X}^{2}-30.826 \mathrm{X}+582.68\left(\mathrm{R}^{2}=0.9401\right)$; $\mathrm{LAP}=-10.071 \mathrm{X}^{3}+131.98 \mathrm{X}^{2}-399.33 \mathrm{X}+1256.6\left(\mathrm{R}^{2}=0.9992\right)$

${ }^{4}$ Regression equation of microbial fractions $\left(\mathrm{mg} \mathrm{kg}^{-1} \mathrm{OM}\right) \times$ time: $\mathrm{PAB}=-0.052 \mathrm{X}^{3}+318.79 \mathrm{X}^{2}-1322.8 \mathrm{X}+4655.8\left(\mathrm{R}^{2}=0.9998\right) ; \mathrm{LAB}=3.6317 \mathrm{X}^{2}-22.837 \mathrm{X}+447.12\left(\mathrm{R}^{2}=0.9730\right)$; $\mathrm{LAP}=-5.2688 \mathrm{X}^{3}+70.583 \mathrm{X}^{2}-222.08 \mathrm{X}+716.06\left(\mathrm{R}^{2}=0.9999\right)$.

disappearance of DM ( $<<0.05$; Contrast 1) (Table 3). The addition of crude glycerin increased DDM, regardless of the additive $(\mathrm{P}<0.05$; Contrasts 2 and 3$)$ and reduced the disappearance of NDF when combined with essential oils $(\mathrm{P}<0.05$; Contrast 2$)$. A reduction was observed in the production of $\mathrm{CH}_{4}$ and $\mathrm{CO}_{2} \mathrm{~mL} \mathrm{gd}^{-1}$ when crude glycerin was combined with sodium monensin $(\mathrm{P}<0.05$; Contrast 3); and when combined with essential oils, it reduced the production of $\mathrm{CO}_{2}$ in $\mathrm{mL} \mathrm{gd}^{-1}(\mathrm{P}<0.05$; Contrast 2). Treatments containing sodium monensin had lower $\mathrm{CH}_{4}$ production in $\mathrm{mL} \mathrm{g}^{-1}$ and $\mathrm{CH}_{4}$ and $\mathrm{CO}_{2}$

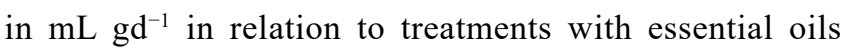
$(\mathrm{P}<0.05$; Contrast 4$)$.

\section{Discussion}

The experimental diets presented similar levels of metabolizable energy and crude protein; however significant differences in DMI and digestibility of DM and nutrients were observed. The reduction in DMI, when crude glycerin was combined with food additives, can be explained by higher energy intake of this byproduct, given the absence of cell wall and rapid fermentation in the rumen, being readily used as an energy substrate by rumen microorganisms or directly absorbed by rumen papillae (Ferraro et al., 2009; Mach et al., 2009).

In addition, the combination of crude glycerin with sodium monensin resulted in a greater reduction in DMI by animals, probably due to the modulation of food intake generated by sodium monensin. According to Schelling (1984), sodium monensin decreases animal intake, causing a feeding modulation, which makes animals visit the feed bunkers more frequently, but they ingest small quantities at a time; therefore, there is also a reduction in metabolic disorders index caused by excessive feed intake, especially non-fiber carbohydrates. In addition, glycerol has propionate as the main final product, a satiety regulator, due to its hypophagic effect (Baile, 1971; Anil and Forbes, 1980; Allen, 2000).

The increases observed for in vitro $\mathrm{DM}, \mathrm{OM}, \mathrm{ADF}$, and NFC digestibility when crude glycerin was combined with food additives can be explained by better synchronization (energy and nitrogen) between the ingredients of these diets. The addition of crude glycerin caused an increase in the level of urea, about $7 \mathrm{~g} \mathrm{~kg}^{-1}$ DM. Probably, urea, source of non-protein nitrogen of rapid release in the rumen, and crude glycerin, energy source readily available in the rumen, simultaneously provided substrates for microbial growth and maintenance, thereby increasing utilization of diets. 
On the other hand, the excess of readily available protein may have reduced the formation of microbial protein in the rumen during the day, facilitating food protein escape from the rumen, which may have been impaired in vitro $\mathrm{CP}$ and NFC digestibility.

Moreover, the food additive sodium monensin was more efficient on the ruminal digestion in relation to essential oils, despite leading to a lower DMI. This result can be because sodium monensin increases energy efficiency, mainly due to the increase in propionic acid production over the acetate (McGuffey et al., 2001). In turn, essential oils have a range of active ingredients newly studied and their action has not been fully elucidated yet.

The combination crude glycerin with food additives did not affect fiber digestibility, diverging from data reported in the literature when crude glycerin was added to diets (Donkin, 2008; Shin et al., 2012; van Cleef et al., 2015). Possibly, the combination of crude glycerin with food additives provided appropriate levels of $\mathrm{pH}$ and $\mathrm{NH}_{3}-\mathrm{N}$ for rumen fermentation and microbial growth. According to Hoover (1986), ruminal $\mathrm{pH}$ plays the major influence on the reduction of fiber degradation. When $\mathrm{pH}$ reaches values of 5.5 or 5.0 , there is an inhibition of cellulolytic microorganisms. In this study, the mean $\mathrm{pH}$ values were greater than 6.09 .

The concentrations of ruminal $\mathrm{NH}_{3}-\mathrm{N}$ were sufficient for bacterial growth in all treatments $\left(20.22 \mathrm{mg} \mathrm{dL}^{-1}\right)$. In agreement with Preston (1986), the minimal concentration of $5 \mathrm{mg} \mathrm{NH}-\mathrm{N} \mathrm{dL}^{-1}$ is sufficient for microbial growth; however, the concentration should be above $10 \mathrm{mg} \mathrm{dL}^{-1}$, for increase in ruminal digestion of DM, and higher than $20 \mathrm{mg} \mathrm{dL}^{-1}$, for increase in DMI (Leng, 1990). The reductions in concentrations of $\mathrm{NH}_{3}-\mathrm{N}$ observed in treatments with sodium monensin, with or without crude glycerin, can be related to improved protein utilization by microorganisms or because proteolytic bacteria and amino acid-fermenting bacteria are sensitive to ionophores (Lana and Russel, 1996), with higher rumen protein bypass.

Given the synergy found between $\mathrm{pH}$ values and concentrations of $\mathrm{NH}_{3}-\mathrm{N}$ in the rumen, there were no significant differences between the concentrations of microorganisms ( $\mathrm{PAB}, \mathrm{LAP}$, and $\mathrm{LAB})$ in the different sampling times. The reduction in the amount of DM and $\mathrm{OM}$ in $\mathrm{mg} \mathrm{L}^{-1}$ rumen fluid with the combination of crude glycerin and essential oils can be explained by rapid fermentation of crude glycerin into propionate via the succinate pathway, not generating dramatic reductions in ruminal $\mathrm{pH}$, and providing a favorable environment for colonization of new dietary substrates (Donkin, 2008; Wang et al., 2009).
Reductions observed for $\mathrm{CH}_{4}$ and $\mathrm{CO}_{2}$ production in $\mathrm{mL} \mathrm{gd}^{-1}$ in diets containing food additives and greater reductions when crude glycerin was added can be primarily explained by a greater disappearance of DM and also by the improved energy efficiency of these diets, probably due to increase in propionic acid production and reduction in acetate/propionate ratio in the rumen (McGuffey et al., 2001). Van Cleef et al. (2015) verified a linear increase in propionic acid production with increasing inclusion of crude glycerin. According to Stradiotti Júnior et al. (2004), the ruminal environment presents an inverse relationship between the production of $\mathrm{CH}_{4}$ and propionic acid. The mechanism that justifies this inverse relationship lies in the routing of $\mathrm{H}^{+}$and $\mathrm{CO}_{2}$, which would be available for methanogenesis, surplus of acetate production, to propionate production, and, considering that crude glycerin is mostly fermented into propionate, there is reduction of gas production, particularly $\mathrm{CH}_{4}$.

In addition, the greatest reductions in greenhouse gas production compared with the control diet were found when crude glycerin was combined with sodium monensin, about 60.38 and $31.83 \%$ reduction for $\mathrm{CH}_{4}$ and $\mathrm{CO}_{2}$, respectively. Treatments with sodium monensin and essential oils drastically decreased the production of $\mathrm{CH}_{4}$ $\left(\mathrm{mL} \mathrm{gd}^{-1}\right)$, respectively, in 50.16 and $40.44 \%$, and $\mathrm{CO}_{2}$ $\left(\mathrm{mL} \mathrm{gd}^{-1}\right)$ in 16.90 and $8.91 \%$, when compared with the control diet. The combination of crude glycerin and sodium monensin was more efficient as to the utilization of gross energy, by reducing by more than half the production of greenhouse gases. Pedreira and Primavesi (2006) claimed that the production of enteric $\mathrm{CH}_{4}$ is responsible for the loss of 6 to $18 \%$ of gross dietary energy during the rumen fermentation process.

The reduction in NDF disappearance observed when crude glycerin was combined with essential oils is likely explained by the in vitro incubation time $(12 \mathrm{~h})$. The presence of crude glycerin may have influenced the DNDF, as it contains no fiber in the composition, negatively affecting the growth of some cellulolytic microorganisms, thereby decreasing the DNDF.

\section{Conclusions}

The addition of crude glycerin at $200 \mathrm{~g} \mathrm{~kg}^{-1}$ dry matter in the total diet combined with food additives causes a reduction in dry matter intake, increase of in vitro dry matter digestibility, and decrease of in vitro crude protein digestibility. Crude glycerin can be combined with either sodium monensin or essential oil without impairing rumen fermentation, being effective in reducing gas methane 
production. The combination of crude glycerin with sodium monensin enables more efficient utilization of the diet by the animal.

\section{Acknowledgments}

Authors thank the Fundação de Amparo à Pesquisa do Estado de São Paulo (FAPESP), for the financial support (grant \#2012/12779-0), and Caramuru Alimentos S.A., for providing part of the ingredients used in this research.

\section{References}

Allen, M. S. 2000. Effects of diet on short-term regulation of feed intake by lactating dairy cattle. Journal of Dairy Science 83:15981624. https://doi.org/10.3168/jds.S0022-0302(00)75030-2

Almeida, M. T. C.; Ezequiel, J. M. B.; Paschoaloto, J. R.; Perez, H. L.; Carvalho, V. B.; Castro Filho, E. S. and van Cleef, E. H. C. B. 2017. Effects of high concentrations of crude glycerin in diets for feedlot lambs: feeding behaviour, growth performance, carcass and non-carcass traits. Animal Production Science 58:1271-1278. https://doi.org/10.1071/AN16628

Anil, M. H. and Forbes, J. M. 1980. Feeding in sheep during intraportal infusions of short-chain fatty acids and the effect of liver denervation. Journal of Physiology 298:407-414. https://doi.org/10.1113/jphysiol.1980.sp013090

AOAC - Association of Official Analytical Chemistry. 2000. Official methods of analysis. 17th ed. AOAC International, Arlington, VA.

Azzaz, H. H.; Murad, H. A. and Morsy, T. A. 2015. Utility of ionophores for ruminant animals: a review. Asian Journal of Animal Sciences 9:254-265. https://doi.org/10.3923/ajas.2015.254.265

Baile, C. A. 1971. Metabolites as feedbacks for control of feed intake and receptor sites in goats and sheep. Physiology \& Behavior 7:819-826. https://doi.org/10.1016/0031-9384(71)90046-1

Benchaar, C.; Petit, H. V.; Berthiaume, R.; Whyte, T. D. and Chouinard, P. Y. 2006. Effects of addition of essential oils and monensin premix on digestion, ruminal fermentation, milk production, and milk composition in dairy cows. Journal of Dairy Science 89:4352-4364. https://doi.org/10.3168/jds.S00220302(06)72482-1

Busquet, M.; Calsamiglia, S.; Ferret, A. and Kamel C. 2005a. Screening for effects of plant extracts and active compounds on daily cattle rumen microbial fermentation in a continuous culture system. Animal Feed Science and Technology 123-124:597-613. https://doi.org/10.1016/j.anifeedsci.2005.03.008

Busquet, M.; Calsamiglia, S.; Ferret, A.; Cardozo, P. W. and Kamel C. 2005b. Effects of cynnamaldehyde and garlic oil on rúmen microbial fermentation in a dual flow continuous culture. Journal of Dairy Science 88:2508-2516. https://doi.org/10.3168/jds. S0022-0302(05)72928-3

Cecava, M. J.; Merchen, N. R.; Gay, L. C. and Berger L. L. 1990. Composition of ruminal bacteria harvested from steers as influenced by dietary energy level, feeding frequency, and isolation techniques. Journal of Dairy Science 73:2480-2488. https://doi.org/10.3168/jds.S0022-0302(90)78933-3

Chaudhry, A. S. and Khan, M. M. H. 2012. Impacts of different spices on in vitro rumen dry matter disappearance, fermentation and methane of wheat or ryegrass hay based substrates. Livestock Science 146:84-90. https://doi.org/10.1016/j.livsci.2012.01.007
CNCPS - Cornell Net Carbohydrate and Protein System. 2000 Version 5.0.40. Cornell University.

Cruz, O. T. B.; Valero, M. V.; Zawadzki, F.; Rivaroli, D. C.; Prado, R. M.; Lima, B. S. and Prado, I. N. 2014. Effect of glycerine and essential oils (Anacardium occidentale and Ricinus communis) on animal performance, feed efficiency and carcass characteristics of crossbred bulls finished in a feedlot system. Italian Journal of Animal Science 13:790-797. https://doi.org/10.4081/ijas.2014.3492

Dewulf, J.; Catry, B.; Timmerman, T.; Opsomer, G.; Kruif, A. and Maes, D. 2007. Tetracycline-resistence in actosepositive enteric coliforms originating from Belgian fattening pigs: degree of resistence, multiple resistence and risk factors. Preventive Veterinary Medicine 78:339-351.

Donkin, S. S. 2008. Glycerol from biodiesel production: the new corn for dairy cattle. Revista Brasileira de Zootecnia 37(supl. especial):280-286. https://doi.org/10.1590/S151635982008001300032

Duarte, M. C. T.; Leme, E. E.; Delarmelina, C.; Soares, A. A.; Figueira, G. M. and Sartoratto, A. 2007. Activity of essential oils from Brazilian medicinal plants on Escherichia coli. Journal of Ethnopharmacology 111:197-201. https://doi.org/10.1016/j. jep.2006.11.034

Ezequiel, J. M. B.; Sancanari, J. B. D.; Machado Neto, O. R.; Da Silva, Z. F.; Almeida, M. T. C.; Silva, D. A. V.; Van Cleef, F. O. S. and Van Cleef, E. H. C. B. 2015. Effects of high concentrations of dietary crude glycerin on dairy cow productivity and milk quality. Journal of Dairy Science 98:8009-8017. https://doi.org/10.3168/ jds.2015-9448

Favaro, V. R.; Ezequiel, J. M. B.; Almeida, M. T. C.; D’Aurea, A. P.; Paschoaloto, J. R.; van Cleef, E. H. C. B.; Carvalho, V. B. and Junqueira, N. B. 2016. Carcass traits and meat quality of Nellore cattle fed different non-fiber carbohydrates sources associated with crude glycerin. Animal 10:1402-1408. https://doi.org/10.1017/ S1751731116000094

Ferraro, S. M.; Mendoza, G. D.; Miranda, L. A. and Gutiérrez, C. G. 2009. In vitro gas production and ruminal fermentation of glycerol, propylene glycol and molasses. Animal Feed Science and Technology 154:112-118. https://doi.org/10.1016/j. anifeedsci.2009.07.009

Hendrix, D. L. 1993. Rapid extraction and analysis of nonstructural carbohydrates in plant tissues. Crop Science 33:1306-1311. https://doi.org/10.2135/cropsci1993.0011183X003300060037x

Hoover, W. H. 1986. Chemical factors involved in ruminal fiber digestion. Journal of Dairy Science 69:2755-2766. https://doi.org/10.3168/jds.S0022-0302(86)80724-X

Jesus, E. F.; Del Valle, T. A.; Calomeni, G. D.; Silva, T. H.; Takiya, C. S.; Vendramini, T. H. A.; Paiva, P. G.; Silva, G. G.; Netto, A. S. and Rennó, F. P. 2016. Influence of a blend of functional oils or monensin on nutrient intake and digestibility, ruminal fermentation and milk production of dairy cows. Animal Feed Science and Technology 219:59-67. https://doi.org/10.1016/j. anifeedsci.2016.06.003

Lana, R. P. and Russell, J. B. 1996. Use of potassium depletion to assess adaptation of ruminal bacteria to ionophores. Applied Environmental Microbiology 62:4499-4503.

Leng, R. A. 1990. Factors affecting the utilization of "poor-quality" forages by ruminants particularly under tropical conditions. Nutrition Research Reviews 3:277-303. https://doi.org/10.1079/ NRR19900016

Mach, N.; Bach, A. and Devant, M. 2009. Effects of crude glycerin supplementation on performance and meat quality of Holstein bulls fed high-concentrate diets. Journal of Animal Science 87:632-638. https://doi.org/10.2527/jas.2008-0987 
Martin, C.; Williams, A. G. and Michalet-Doreau, B. 1994. Isolation and characteristics of the protozoa and bacterial fractions from bovine and ruminal contents. Journal of Animal Science 72:2962-2968.

McGuffey, R. K.; Richardson, L. F. and Wilkinson, J. I. D. 2001. Ionophores for dairy cattle: Current status and future outlook. Journal of Dairy Science 84:194-203. https://doi.org/10.3168/jds. S0022-0302(01)70218-4

NRC - National Research Council. 1996. Nutrient requirement of beef cattle. 7th ed. National Academy Press, Washington, DC.

Pedreira, S. M. and Primavesi, O. 2006. Impacto da produção animal sobre o ambiente. p.497-511. In: Nutrição de ruminantes. Berchielli, T. T.; Pires, A. V. and Oliveira, S. G., ed. Funep, Jaboticabal, SP.

Pell, A. N. and Schofield, P. 1993. Computerized monitoring of gas production to measure forage digestion in vitro. Journal of Dairy Science 76:1063-1073. https://doi.org/10.3168/jds.S00220302(93)77435-4

Pereira, E. M. O.; Ezequiel, J. M. B.; Biagioli, B. and Feitosa, J. 2006. Methane and carbon dioxide production in vitro in ruminal liquid from different types of bovines fed with total mixed ration. Archivos Latino Americanos de Producción Animal 14:120-127.

Prado, I. N.; Cruz, O. T. B.; Valero, M. V.; Zawadzki, F.; Eiras, C. E.; Rivaroli, D. C.; Prado, R. M. and Visentainer, J. V. 2015. Effects of glycerin and essential oils (Anacardium occidentale and Ricinus communis) on the meat quality of crossbred bulls finished in a feedlot. Animal Production Science 56:2105-2114. https://doi.org/10.1071/AN14661

Preston, T. R. 1986. Better Utilization of crop residues and by-products in animal feeding: research guidelines - 2. A pratical manual for research workers. FAO, Rome. 154p.

Ray, K. A.; Warnick, L. D.; Mitchell, R. M.; Kaneene, J. B.; Ruegg, P. L.; Wells, S. J.; Fossler, C. P.; Halbert, L. W. and May, K. 2007. Prevalence of antimicrobial resitence among Salmonella on Midwest and northeast USA dairy farms. Preventive Veterinary Medicine 79:204-223. https://doi.org/10.1016/j. prevetmed.2006.12.001

Schelling, G. T. 1984. Monensin mode of action in the rumen. Journal of Animal Science 58:1518-1527. https://doi.org/10.2527/ jas1984.5861518x
Shin, J. H.; Wang, D.; Kim, S. C.; Adesogan, A. T. and Staples, C. R. 2012. Effects of feeding crude glycerin on performance and ruminal kinetics of lactating Holstein cows fed corn silage or cottonseed hull-based, low-fiber diets. Journal of Dairy Science 95:4006-4016. https://doi.org/10.3168/jds.2011-5121

Sniffen, C. J.; O’Connor, J. D.; van Soest, P. J.; Fox, D. G. and Russell, J. B. 1992. A net carbohydrate and protein system for evaluating cattle diets: II. Carbohydrate and protein availability. Journal of Animal Science 70:3562-3577. https://doi. org/10.2527/1992.70113562x

Stradiotti Júnior, D.; Queiroz, A. C.; Lana, R. P.; Pacheco, C. G.; Camardelli, M. M. L.; Detmann, E.; Eifert, E. C.; Nunes, P. M. M. and Oliveira, M. V. M. 2004. Ação do extrato de própolis sobre a fermentação in vitro de diferentes alimentos pela técnica de produção de gases. Revista Brasileira de Zootecnia 33:1093-1099. https://doi.org/10.1590/S1516-35982004000400030

Tan, H. W.; Aziz, A. R. A. and Aroua, M. K. 2013. Glycerol production and its applications as a raw material: a review. Renewable and Sustainable Energy Reviews 27:118-127. https://doi.org/10.1016/j. rser.2013.06.035

Valero, M. V.; Prado, R. M.; Zawadzki, F.; Eiras, C. E.; Madrona, G. S. and Prado, I. N. 2014. Propolis and essential oils additives in the diets improved animal performance and feed efficiency of bulls finished in feedlot. Acta Scientiarum. Animal Sciences 36:419426. https://doi.org/10.4025/actascianimsci.v36i4.23856

van Cleef, E. H. C. B.; Almeida, M. T. C.; Perez, H. L.; van Cleef , F. O. S.; Silva, D. A. V. and Ezequiel, J. M. B. 2015. Crude glycerin changes ruminal parameters, in vitro greenhouse gas profile, and bacterial fractions of beef cattle. Livestock Science 178:158-164. https://doi.org/10.1016/j.livsci.2015.06.016

Van Soest, P. J. and Wine, R. H. 1967. Use of detergents in the analysis of fibrous feeds. IV. Determination of plant cell wall constituents. Journal of the Association of Official Analytical Chemists 50:50-55.

Wang, C.; Liu, Q.; Huo, W. J.; Yang, W. Z.; Dong, K. H.; Huang, Y. X. and Guo, G. 2009. Effects of glycerol on rumen fermentation, urinary excretion of purine derivatives and feed digestibility in steers. Livestock Science 12:15-20. https://doi.org/10.1016/j. livsci.2008.05.010 